\title{
Amaurodon mustialaënsis (Basidiomycota, Thelephoraceae) new to Italy
}

\author{
Alfonso La Rosa, Riccardo Compagno \& Alessandro Saitta \\ Department of Agricultural and Forest Sciences, Università di Palermo, I-90128, Palermo, Italy. \\ E-mail: alessandro.saitta@unipa.it
}

\begin{abstract}
Amaurodon mustialaënsis is reported for the first time from Italy. Based on Italian specimens, a brief description, microscopical and macroscopical photographs, ecological and distributional data of this rare taxon are presented.
\end{abstract}

\section{INTRODUCTION}

Amaurodon J. Schröter includes ten species distributed worldwide. Amaurodon is not recognized by Stalpers (1993) as a thelephoroid genus, but Kõljalg (1996) and Larsson et al. (2004) confirmed its classification among Thelephorales Corner ex Oberw. as a distinct monophyletic genus. Amaurodon belongs to the group of resupinate Thelephorales together with three other genera, Tomentellopsis Hjortstam, Pseudotomentella Svrček and Tomentella Pers. ex Pat. (Kõljalg 1996). Resupinate Thelephorales includes about 100 species (Kirk et al. 2008). A. acquicoeruleus Agerer has been reported only from Japan (Agerer and Bougher, 2001) and is characterized by the presence of bluish spores in water. A. angulisporus Gardt \& Yorou was recently reported from Togo and Burkina Faso (West Africa), characterized by pale blue spores in water (Gardt et al., 2011). Within the genus Amaurodon only A. viridis (Alb. \& Schwein.) J. Schröt. has previously been recorded in Italy (Saitta et al., 2011). A. mustialaënsis (P. Karst.) Kõljalg \& K.H. Larss. is easily recognizable microscopically for the smooth basidiospores, and macroscopically it differs from the widely distributed $A$. viridis by virtue of a quite smooth hymenophore, or the presence of very rare warts.

\section{MATERIALS \& METHODS}

Basidiomata were identified while fresh and microscopic features were observed in $\mathrm{H}_{2} \mathrm{O}, 3 \%$ $\mathrm{KOH}$ solution, Melzer's reactive, and Cotton blue in lactic acid, using a Leica microscope DMLB. Spore measurements were based on 50 observations of dried specimens. Nomenclature follows Mycobank (http://www.mycobank.org). The description is based on personal observations of fresh and dried specimens. The specimens are kept in the fungal dried reference collection of the recently established mycological herbarium of the new Department of Agricultural and Forest Sciences (activated by the University of Palermo on 2014), provisional numbers SAF 003, SAF 004.

\section{RESULTS Identification}

AmaURodon mustialä̈nsis (P. Karst.) Kõljalg \& K.H. Larss. (Figs 1-2).

Basidiomata annual, resupinate, continuous, arachnoid, pellicular, up to $8 \mathrm{~cm}$ in diam., fragile and easily separable from the substrate. Hymenophoral surface, smooth or slightly granulose, bluish in the fresh specimens, green-yellow when dried. Margin sterile, white, arachnoid. Subiculum thin, white-greyish.

Hyphal system monomitic. Subicular hyphae cylindrical, thin-walled, 2.2-4 $\mu \mathrm{m}$ wide, with clamps. Subhymenial hyphae with clamps, 2.5-4 $\mu \mathrm{m}$ wide, thin-walled.

Basidia tetrasporic, basally clamped, utriform, often attenuated, 22-30 × 4.5-5.5, sterigmata 1.8-2.7 $\mu \mathrm{m}$ long. Basidiospores thick-walled, smooth, (4.5-)4.8-5.2 × 3.5-4 (-4.2) $\mu \mathrm{m}$, subglobose to ellipsoid in lateral and frontal face, apiculus prominent, with a violet reaction after few seconds in 3\% $\mathrm{KOH}$ solution, hyaline in water.

Specimen studied: Italy, Appennino Lucano, Abetina di Laurenzana, Laurenzana, Potenza, $40.41267^{\circ} \mathrm{N}$, $15.96197^{\circ} \mathrm{E}$, on the bark of a fallen trunk of Abies alba Mill. in a mixed forest of $A$. alba and Fagus sylvatica L., 1200 m a. s. 1., 31 Oct 2012, coll. A. Saitta \& A. La Rosa (SAF 003; SAF 004). 

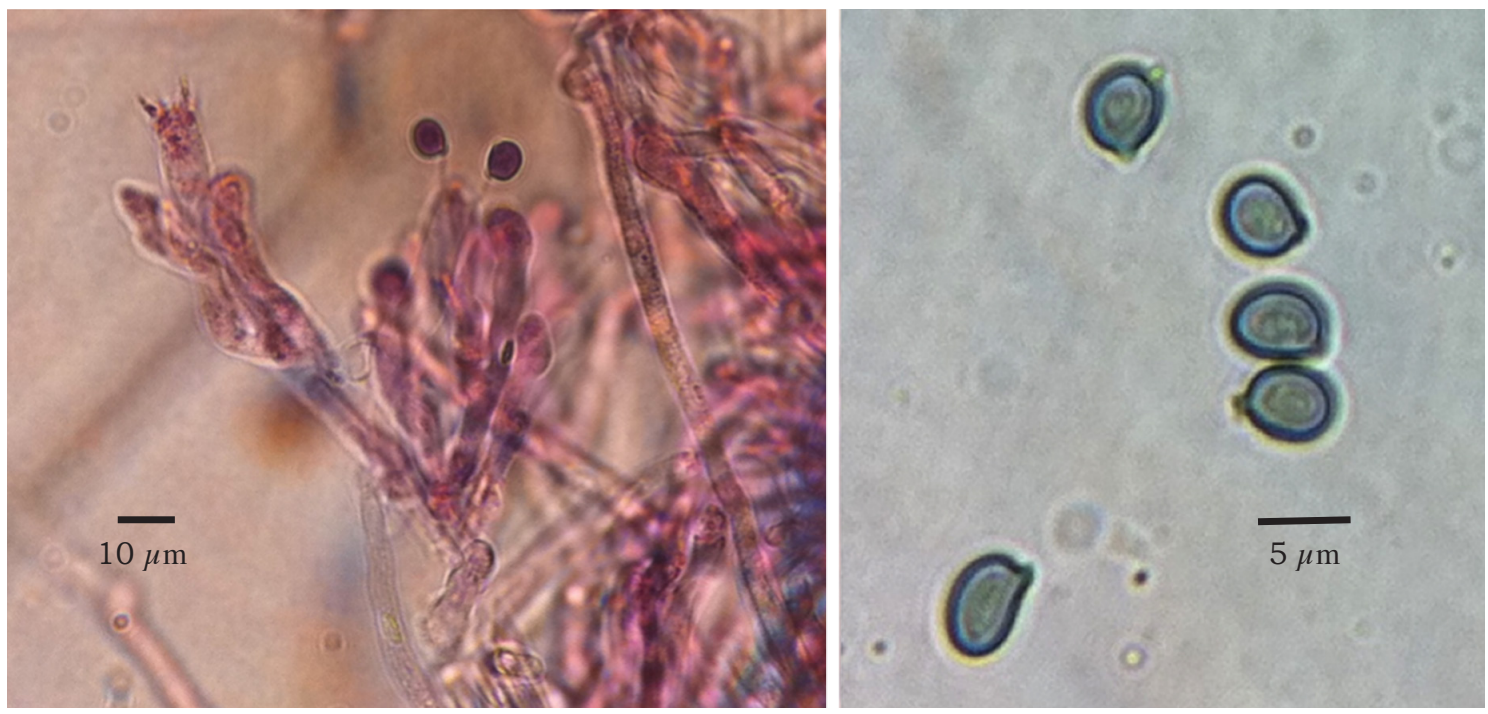

Fig. 1. Basidia and spores of Amaurodon mustialaënsis

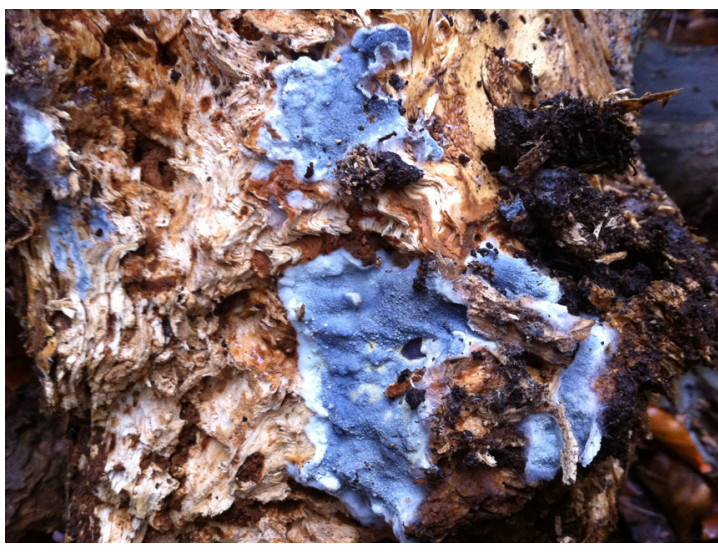

Fig. 2. Basidiomata of Amaurodon mustialaënsis

\section{DISCUSSION}

Distinctly smooth subglobose basidiospores are reported within the genus Amaurodon only for A. mustialaënsis. The other nine known Amaurodon species have echinulate spores which are hyaline or bluish in $\mathrm{KOH}$. Among these A. viridis is widely distributed in the Mediterranean region and is common in oak woodlands, especially in Quercus ilex L. communities.

A. mustialaënsis is included in the Danish (DD), Estonian (CR) and Swedish (DD) Red List of threatened fungi. The basidiomata were collect- ed on degraded wood of Abies alba (with white rot) in a mixed forest of $A$. alba and $F$. sylvatica.

A. mustialaënsis is rare but widely distributed in the Northern Hemisphere (Kõljalg, 1996). The European distribution is limited to Denmark, Estonia, Finland, France, Germany, Russia, Slovakia, Spain, Sweden, and the United Kingdom (http://data.gbif.org/occurrences/125717190/, http://data.gbif.org/occurrences/125717190/, Bourdot \& Galzin, 1928; Wakefield, 1952; Jülich, 1984; Gärdenfors, 2005; Melo et al., 2006; Čížek et al., 2007; PérezGorjón et al., 2008; Shiryaev, 2008; Kotiranta \& Saarenoksa, 2009), Armenia and Dagestan in Asia (Kõljalg, 1996), and Canada and the USA in North America (Gilbertson, 1974; Ginns, 1989).

As reported by Gardt et al. (2011), the genus Amaurodon is associated with a wide range of angiosperm and gymnosperm species. Previously it was collected on wood of Castanea sativa Mill. (Melo et al., 2006), Fagus orientalis Lipsky (Kõljalg, 1996), Picea abies (L.) H. Karst. (http://elurikkus.ut.ee), Platanus orientalis L. (Kõljalg, 1996), Populus nigra L. (Čížek et al., 2007), Quercus pyrenaica Willd. (Pérez-Gorjón et al., 2008), and Quercus robur L. (Shiryaev 2008).

This first record of A. mustialaënsis in Italy widens the knowledge of the distribution and ecology of this rare, or at least seldom collected species in Europe. 
The forest "Abetina of Laurenzana" is a relictual forest of Abies alba of Appennino Lucano, Southern Italy. This type of vegetation is included in the priority Habitats of Annex I of the Directive 92/43/EEC and its interpretation manual for Italy (Blasi et al., 2007). A. alba grows among oak and beech to form consortia that can be framed in the habitat "Apennine beech forests with Abies alba and beech forests with Abies nebrodensis (*9220)". The "Abetina of Laurenzana" is a Natural Reserve belonging to the "Parco Nazionale dell'Appennino Lucano-Val d'Agri-Lagonegrese".

\section{ACKNOWLEDGMENTS}

Financial support by "Ente Parco Nazionale dell'Appennino Lucano, Val D’Agri, Lagonegrese" (Agreement with Department of Agricultural and Forest Science, University of Palermo, Rep. $n^{\circ}$ 037, 1 October 2012, scientific coordinator Prof. Giuseppe Venturella). The authors would like to thank Mr. Tony Garner (UK) for his help with linguistic revision.

\section{REFERENCES}

Agerer, R. \& Bougher, N. L. 2001. Amaurodon aquicoeruleus (Thelephoraceae, Hymenomycetes, Basidiomycota), a new species from Australia with spores distinctly blue in water. Australian Systematic Botany 14: 599-606. http://dx.doi. org/10.1071/SB00030

Blasi, C., Boitani, L., La Posta, S., Manes F. \& Marchetti M. (eds) 2007. Biodiversity in Italy. Contribution to the national biodiversity strategy. Roma, Palombi \& Partner S.r.L. 460 pp.

Bourdot, H. \& Galzin, A. 1927. Hymenomycètes de France. Sceaux. $761 \mathrm{pp}$

Čižek, K., Hagara, L. \& Lizoň, P. 2007. Amaurodon mustialaënsis (Basidiomycetes, Thelephoraceae), novy druh slovenske mykoflory. Czech Mycology 59(2): 177-183.

Gärdenfors, U. (ed.) 2005. Rödlistade arter $i$ Sverige 2005. The 2005 Red List of Swedish Species. Uppsala. 496 pp.

Gardt, S., Yorou, N. S., Guissou, M. L., Guelly, A. K. \& Agerer, R. 2011. Amaurodon angulisporus (Basidiomycota, Fungi), a new species from West
Africa identified by molecular and anatomical features. Nova Hedwigia 93: 237-247. http:/ /dx.doi. org/10.1127/0029-5035/2011/0093-0237

Gilbertson, R. L. 1974. Fungi that decay ponderosa pine. Tucson. $197 \mathrm{pp}$.

Ginns, J. 1989. Description and notes for some unusual North American corticioid fungi. Memoirs of the New York Botanical Garden 49: 129-137.

Jülich, W. 1984. Die Nichtblatterpilze, Gallertpilze und Bauchpilze. In: Gams W. (ed.), Kleine Kryptogamenflora, Vol. II b/1. Jena. 626 pp.

Kirk, P. M., Cannon, P. F., Minter, D. W. \& Stalpers, J. A. 2008. Dictionary of the fungi. 10th ed. CABI Europe, UK. 771 pp.

Kõljalg, U. 1996. Tomentella (Basidiomycota) and related genera in temperate Eurasia. Synopsis fungorum 9: 1-213.

Kotiranta, H. \& Saarenoksa, R. 1993. Rare Finnish Aphyllophorales (Basidiomycetes), plus two new combinations in Efibula. Annales Botanici Fennici 30: 211-249.

Larsson, K. H., Larsson, E. \& Kõljalg, U. 2004. High phylogenetic diversity among corticioid basidiomycetes. Mycological Research 108: 983-1002. http://dx.doi.org/10.1017/S0953756204000851

Melo, I., Salcedo, I. \& Telleria, M. T. 2006. Contribution to the knowledge of tomentelloid fungi in the Iberian Peninsula. V. Nova Hedwigia 82: 167-187. http://dx.doi.org/10.1127/00295035/2006/0082-0167

Pérez-Gorjón, S., Bernicchia, A. \& Sánchez-Sánchez, J. 2008. Amaurodon mustialaënsis (Thelephorales, Basidiomycota), una rara espece en la penisula iberica. Boletín de la Sociedad Micológica de Madrid 32: 85-90.

Saitta, A., Bernicchia, A., Gorjón, S. P., Altobelli, E., Granito, V. M., Losi, C., Lunghini, D., Maggi, O., Medardi, G., Padovan, F., Pecoraio, L., Vizzini, A. \& Persiani, A. M. 2011. Biodiversity of wooddecay fungi in Italy. Plant Biosystems 145(4): 958-968. http://dx.doi.org/10.1080/11263504 /2011.633114.

Shiryaev, A. 2008. Diversity and distribution of thelephoroid fungi (Basidiomycota, Thelephorales) in the Sverdlovsk region, Russia. Folia Cryptogamica Estonica 44: 131-141.

Stalpers, J. A. 1993. The Aphyllophoraceous fungi I. Keys to the species of the Thelephorales. Studies in Mycology 35: 1-168.

Wakefield, E. M. 1952. New or rare British Hymenomycetes (Aphyllophorales). Transaction of the British Mycological Society 35: 34-65. http:/ / dx.doi. org/10.1016/S0007-1536(52)80006-3 
60 Folia Cryptog. Estonica 